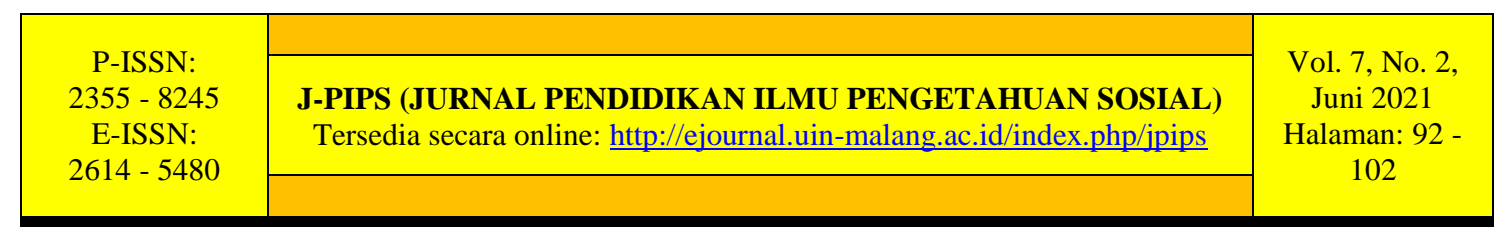

\title{
Pengembangan Bahan Ajar Digital Berbasis STEM dengan Pendekatan Eco-Spatial Behavior Materi Kependudukan
}

\author{
Kusuma Dewi ${ }^{1}$, Sumarmi ${ }^{2}$, Alfyananda Kurnia Putra ${ }^{3}$ \\ ${ }^{1,2,3}$ Universitas Negeri Malang, Jl. Semarang No. 5, Malang, Jawa Timur, Indonesia \\ ${ }^{1}$ kusumadewi.um@gmail.com, ${ }^{2}$ sumarmi.fis@um.ac.id, ${ }^{3}$ alfyananda.fis@um.ac.id
}

Diterima: 31-03-2021.; Direvisi: 18-06-2021; Disetujui: 18-06-2021

Permalink/DOI: 10.15548/jpips.v7i2.11960

\begin{abstract}
Abstrak: Tuntutan dan tantangan perkembangan abad 21 terjadi di semua bidang terutama dalam proses pembelajaran dan kompetensi siswa. Pencapaian tujuan pembelajaran abad 21 diimplementasikan dalam kurikulum 2013 salah satunya melalui pengembangan Bahan Ajar Digital (BAD). Pengembangan BAD menggunakan pendekatan STEM dan eco-spatial behavior pada materi Kependudukan. Diharapkan dapat menghasilkan siswa yang mampu berinovasi dan bersaing di era digital dengan tetap menjaga keberlangsungan lingkungan. Model penelitian pengembangan menggunakan prosedur ADDIE (Analysis, Design, Development, Implementation, and Evaluation). Jenis data terdiri dari kualitatif dan kuantitatif. Pengumpulan data menggunakan teknik wawancara, angket, dan dokumentasi dengan teknik analisis deskriptif persentase. Uji coba produk pengembangan dilakukan di kelas XII IIS MA AlIttihad Poncokusumo. Hasil uji kelayakan memperoleh 87\% dari tanggapan siswa, 95\% tanggapan guru, $90 \%$ dari validator materi, dan $95 \%$ dari validator media. Dengan demikian, BAD tersebut sangat layak digunakan dalam pembelajaran Geografi.
\end{abstract}

\section{Kata Kunci: Bahan Ajar Digital; STEM; Eco-Spatial Behavior}

\section{Development of STEM-Based Digital Teaching Materials with an Eco- Spatial Behavior Approach for Population Materials}

Abstract: The demands and challenges of $21^{\text {st }}$ century development occur in all areas, especially in the learning process and student competence. The achievement of $21 \mathrm{st}$ century learning objectives is implemented in the 2013 curriculum, one of which is through the development of Bahan Ajar Digital (BAD). Development of BAD uses STEM approaches and eco-spatial behavior in Population materials. It is expected to produce students who are able to innovate and compete in the digital age while maintaining environmental sustainability. The development research model uses the ADDIE procedure (Analysis, Design, Development, Implementation, and Evaluation). The data type consists of qualitative and quantitative. Data collection using interview techniques, questionnaires, and documentation with descriptive percentage analysis techniques. The product development trial was conducted in class XII IIS MA Al-Ittihad Poncokusumo. The feasibility test results obtained $87 \%$ of student responses, $95 \%$ of teacher responses, $90 \%$ of material validators, and $95 \%$ of media validators. Thus, BAD is very feasible to be used in the learning of Geography. 


\section{Keywords: Digital Teaching Materials; STEM; Eco-Spatial Behavior}

\section{PENDAHULUAN}

Tuntutan dan tantangan perkembangan abad 21 terjadi pada semua bidang terutama dalam proses pembelajaran dan kompetensi siswa. Tujuan pembelajaran abad 21 memiliki beberapa subjek yaitu: 1) keterampilan belajar dan berinovasi; 2) keterampilan penggunaan informasi, media, dan teknologi; 3) keterampilan hidup dan berkarir (Hadinugrahaningsih et al., 2017). Pencapaian tujuan pembelajaran abad 21 diimplementasikan dalam kurikulum 2013. Implementasi kurikulum 2013 ini terletak pada penyeimbangan hard skill dan soft skill dengan ranah afektif, kognitif, dan psikomotorik (Kemendikbud, 2014). Salah satu upaya tersebut melalui pengembangan bahan ajar digital.

Bahan ajar digital merupakan salah satu perangkat terpenting dalam pencapaian tujuan pembelajaran. Bahan ajar digital (BAD) meningkatkan kemampuan siswa untuk membaca lebih luas (Karemaker et al., 2017), berkolaborasi dengan lingkungan, termotivasi, menggabungkan ide baru, meningkatkan kognitif (Alan, 2013; Richter \& Courage, 2017). BAD juga dapat meningkatkan kemampuan siswa untuk berpikir kreatif, memecahkan masalah, kritis, dan termotivasi. Hal tersebut dapat mendukung pencapaian tujuan pembelajaran abad 21.

Pengintegrasian pendekatan dalam bahan ajar merupakan topik utama dan perlu diimplementasikan agar tujuan pembelajaran dapat dicapai dengan maksimal. Diharapkan dapat menghasilkan siswa yang mampu memecahkan masalah, berinovasi, dan bersaing dalam era digital dengan tetap menjaga keberlangsungan lingkungan. Sehingga pengembangan bahan ajar digital ini menggunakan pendekatan STEM dan eco-spatial behavior pada materi Kependudukan khususnya pada sub materi faktor dinamika penduduk, proyeksi penduduk, dan perencanaan pembangunan.

STEM (Science, Technology, Engineering, and Mathematics) adalah pendekatan yang mengintegrasikan empat disiplin ilmu yang dapat meningkatkan hasil belajar siswa baik secara akademik maupun non-akademik (Pangesti et al., 2017; Reynolds et al., 2013) dimana diharapkan dapat memberikan pembelajaran bermakna dalam menyeimbangkan antara konsep, pengetahuan, dan keterampilan secara sistematis (Afriana et al., 2016; Barry et al., 2017; Han, 2016). Eco-spatial behavior merupakan pengembangan dari perilaku spasial, dan tidak semua stimulus spasial akan direspons masyarakat dengan perilaku yang sejalan dengan prinsip ekologis (Deliyanto, 2011). Pendekatan ini berfokus pada hubungan timbal balik antara spasial dan perilaku manusia yang sejalan dengan prinsip-prinsip ekologis. Pendekatan ini merupakan perwujudan tata spasial akibat dari tindakan manusia, termasuk di dalamnya perilaku manusia terhadap ruang yang dapat membentuk pola perilaku manusia sesuai dengan prinsip-prinsip ekologi.

Analisis kebutuhan dalam penelitian ini terdapat analisis kebutuhan siswa dan bahan ajar yang sudah ada. Analisis kebutuhan siswa di lokasi penelitian yaitu MA AlIttihad Poncokusumo bahwasanya siswa mengalami kesulitan dalam mempelajari sub materi faktor dinamika penduduk, proyeksi penduduk, dan perencanaan pembangunan. Selain itu siswa memerlukan adanya peta konsep, infografis, gambar, video, dan tautan sehingga membantu pemahaman siswa. Sekolah juga membutuhkan bahan ajar digital untuk menyiapkan digitalisasi sekolah. Siswa juga mengharapkan pembelajaran Geografi dilakukan dengan kegiatan praktikum sehingga dapat mempermudah dalam pemahaman konsep materi. 
Penelitian pengembangan yang akan dilakukan oleh peneliti yaitu pengembangan bahan ajar digital berbasis STEM dengan pendekatan eco-spatial behavior sub-materi Dinamika Kependudukan di Indonesia untuk Perencanaan Pembangunan yang didasarkan pada beberapa analisis kebutuhan sebelumnya. Materi ini merupakan KD 3.5 menganalisis dinamika kependudukan di Indonesia untuk perencanaan pembangunan kelas XI mata pelajaran Geografi. Dalam BAD ini memuat narasi materi pelajaran, infografis, gambar, video, dan tautan. BAD yang dirancang akan dikemas dalam bentuk flipbook. Pendekatan yang digunakan dalam pengembangan BAD ini yaitu mengintegrasikan STEM dan eco-spatial behavior. Pendekatan ini akan menghasilkan siswa yang dapat berperilaku ekologis, memecahkan masalah, berinovasi dan dapat bersaing dalam era digital dan globalisasi.

\section{METODE}

Model penelitian pengembangan menggunakan prosedur ADDIE (Analysis, Design, Development, Implementation, and Evaluation). Prosedur pengembangan pada tahap analisis terdapat tiga tahapan yaitu analisis subjek penelitian, analisis bahan ajar yang sudah ada, dan analisis kurikulum. Pada tahap desain terdiri dari kegiatan penyusunan konsep produk, pengumpulan daftar komponen, dan penyusunan instrumen penelitian. Tahap pengembangan yaitu merealisasikan rancangan yang telah dibuat pada tahapan sebelumnya, memvalidasi, dan merevisi produk berdasarkan hasil angket campuran dari validator. Selanjutnya tahap implementasi yaitu menguji coba kelayakan produk kepada subjek uji coba lapangan sebenarnya yaitu kepada guru dan siswa. Tahap evaluasi yaitu mengevaluasi semua tahapan ADDIE dan menyimpulkan bagaimana hasil dari perhitungan tingkat kelayakan produk oleh uji coba validator, guru, dan siswa.

Jenis data terdiri dari kualitatif dan kuantitatif. Pengumpulan data menggunakan teknik wawancara, lembar kuesioner campuran, dan dokumentasi dengan teknik analisis deskriptif persentase. Uji coba produk pengembangan dilakukan pada kelas XII IIS 3 MA Al-Ittihad Poncokusumo, Kabupaten Malang. Sampel dalam penelitian pengembangan ini berjumlah 15 siswa sebagai uji coba terbatas. Dalam pengolahan data terdapat rumus yang digunakan (Suharsimi, 2006) sebagai berikut:

$$
\mathrm{N}=\frac{x}{x i} \times 100 \%
$$

Rumus yang digunakan untuk memperoleh data keseluruhan:

$$
\mathrm{N}=\sum \frac{x}{x i} \times 100 \%
$$

Keterangan:

$\mathrm{N} \quad$ : Nilai (persentase)

$\mathrm{x} \quad$ : Jumlah skor jawaban responden dalam 1 item

xi : Jumlah skor maksimum dalam 1 item

Klasifikasi kelayakan BAD akan disimpulkan didasarkan pada data persentase sebagai berikut: 
Tabel 1. Kriteria Kelayakan Bahan Ajar

\begin{tabular}{|c|c|c|}
\hline $\begin{array}{c}\text { Tingkat } \\
\text { Pencapaian }\end{array}$ & Kualifikasi & Keterangan \\
\hline $85,01 \%-100 \%$ & Sangat Baik & $\begin{array}{l}\text { Sangat layak /sangat valid / boleh digunakan/tidak perlu } \\
\text { revisi }\end{array}$ \\
\hline $70,01 \%-85 \%$ & Baik & Layak /valid /boleh digunakan/perlu revisi kecil \\
\hline $50,01 \%-70 \%$ & Tidak Baik & $\begin{array}{l}\text { Tidak layak/ tidak valid/ saran tidak boleh digunakan/ perlu } \\
\text { revisi besar }\end{array}$ \\
\hline $01,00 \%-50 \%$ & $\begin{array}{l}\text { Sangat } \\
\text { Tidak Baik }\end{array}$ & Sangat tidak layak/sangat tidak valid/tidak boleh digunakan \\
\hline
\end{tabular}

\section{HASIL DAN PEMBAHASAN}

Penelitian pengembangan ini mengacu pada model pengembangan ADDIE (Analysis, Design, Development, Implementation, and Evaluation). Adapun uraian tahapan pengembangan BAD materi kependudukan sebagai berikut.

\section{Analisis}

Pada tahap analisis terdiri dari beberapa tahapan yaitu analisis subjek penelitian, analisis bahan ajar yang sudah ada, dan analisis kurikulum. Tahapan ini untuk mendapatkan data permasalahan dan merumuskan tujuan penelitian pengembangan. Masalah yang ada di sekolah penelitian, MA Al-Ittihad Poncokusumo dianalisis dengan menggunakan angket kebutuhan bahan ajar. Analisis kebutuhan ini diperuntukkan bagi guru kelas XI dan XII yaitu Ibu Rima Hidayati S.Pd. dan siswa kelas XII IPS 3.

Ditinjau berdasarkan analisis yang telah dilakukan, bahan ajar yang dikembangkan adalah BAD. Bentuk digital ini dipilih oleh peneliti atas dasar analisis kebutuhan bahan ajar. Bahan ajar cetak memiliki beberapa kelemahan yaitu memerlukan biaya mahal, materi menjadi membosankan, mudah hilang, dan berat dibawa siswa (Astriyandi, 2016). Bahan ajar yang dikembangkan berekstensi .html sehingga dapat diakses di laptop maupun smartphone secara online. Dengan format ini maka BAD tidak memerlukan aplikasi khusus untuk membukanya (Ruddamayanti, 2019). BAD dikemas dalam bentuk flipbook. Bentuk ini memudahkan pengguna belajar kapanpun dan dimanapun karena berbentuk elektronik. Dengan demikian BAD dapat memberikan kemudahan dalam pembelajaran jarak jauh (Martha et al., 2018). Software yang digunakan untuk mengembangkan BAD ini yaitu flip PDF Corporate.

BAD dilengkapi beberapa unsur multimedia yaitu video, gambar, foto, teks, dan tautan, namun juga terdapat unsur tabel, grafik, dan infografis. Penggunaan multimedia di dalam bahan ajar menjadi menarik karena memadukan berbagai media pembelajaran sehingga dapat memotivasi siswa untuk belajar mandiri. Unsur link (tautan) yang terhubung dengan internet dalam bahan ajar sangat diutamakan. Dengan pengintergrasian ini, maka menambah nilai jangkauan materi yang luas dalam BAD.

Pendekatan dalam pengembangan bahan ajar ini yaitu mengintegrasikan STEM dengan eco-spatial behavior. STEM Education berarti pendidikan yang mengintegrasikan empat disiplin ilmu untuk mendukung peningkatan hasil belajar siswa secara akademik maupun non-akademik (Pangesti et al., 2017; Reynolds et al., 2013). Selanjutnya pendekatan eco-spatial behavior diharapkan dapat menghasilkan siswa berperilaku ekologis dan berkelanjutan sehingga dapat mendukung pencapaian pembangunan berkelanjutan. Pengembangan bahan ajar digital ini juga didasarkan analisis kurikulum. Kurikulum yang digunakan yaitu kurikulum 2013 revisi. 


\section{Desain}

Tahap kedua dari model pengembangan ADDIE adalah desain. Pada tahapan ini terdiri dari beberapa tahapan yaitu penyusunan konsep produk, pengumpulan daftar komponen, dan penyusunan instrumen penelitian. Tahapan penyusunan konsep produk merupakan tahapan perancangan untuk mengembangkan BAD. Perancangan BAD ini didasarkan pada hasil analisis pada tahap sebelumnya. Bahan ajar yang dikembangkan berekstensi .html yang dapat diakses melalui PC maupun smartphone. Pada tahapan penyusunan konsep produk terdiri dari dua tahapan yaitu pertama dilakukan penyusunan unsur BAD. Unsur ini (Andi, 2011) yaitu judul, petunjuk, kompetensi dasar, materi pokok, informasi pendukung, latihan (kegiatan siswa), dan evaluasi. Tahapan kedua yaitu penyusunan indikator pendekatan yang digunakan dalam pengembangan BAD yaitu pendekatan STEM dan eco-spatial behavior. Adapun uraian penyusunan pendekatan tersebut sebagai berikut.

Tabel 2. Indikator STEM dalam Produk Pengembangan

\begin{tabular}{|c|c|c|}
\hline No & Materi & Indikator STEM dalam Sub-Materi yang Dikembangkan Peneliti \\
\hline 1 & Science & $\begin{array}{l}\text { - Penyusunan materi, informasi pendukung, dan tugas siswa dapat } \\
\text { menstimulus siswa untuk berpikir kritis dan menggunakan keilmuannya } \\
\text { secara ilmiah } \\
\text { - Mencari, mengevaluasi dan mengkomunikasikan informasi }\end{array}$ \\
\hline 2 & Technology & $\begin{array}{l}\text { - Penggunaan alat bantuan dalam mempelajari materi seperti penggunaan } \\
\text { internet, PC, smartphone, kamera, media sosial, dan lain sebagainya. } \\
\text { - } \quad \text { Penggunaan teknologi dalam tugas individu dan tugas kelompok }\end{array}$ \\
\hline 3 & Engineering & $\begin{array}{l}\text { - Terdapat kegiatan siswa berbasis proyek dalam bentuk praktikum } \\
\text { lapangan dan mengintegrasikannya dengan penggunaan teknologi } \\
\text { - Membuat keputusan yang tepat terkait teknologi dan merelasikannya } \\
\text { dengan masyarakat dan lingkungan }\end{array}$ \\
\hline 4 & Mathematics & $\begin{array}{l}\text { - Terdapat materi yang mengarahkan siswa dalam pengaplikasian } \\
\text { matematika dalam permasalahan kehidupan sehari-hari } \\
\text { - Terdapat pengaplikasian matematika dalam kegiatan siswa }\end{array}$ \\
\hline
\end{tabular}

\section{Sumber: Hasil Analisis Peneliti}

Selanjutnya pendekatan eco-spatial behavior dalam pengembangan BAD menggunakan beberapa indikator sebagai berikut.

Tabel 3. Klasifikasi Materi dengan Indikator Eco-spatial Behavior

\begin{tabular}{llll}
\hline No & Materi & \multicolumn{2}{c}{$\begin{array}{l}\text { Indikator Eco-Spatial Behavior dalam Sub-Materi yang Dikembangkan } \\
\text { Peneliti }\end{array}$} \\
\hline 1 & Natalitas & $\bullet$ & $\begin{array}{l}\text { Dapat mengaitkan hubungan antara partisipasi masyarakat dalam } \\
\text { perencanaan pembangunan dengan tingkat keberhasilan menekan angka } \\
\text { kelahiran penduduk yang tinggi }\end{array}$ \\
\hline 2 & Mortalitas & $\bullet$ & $\begin{array}{l}\text { Dapat mengambil keputusan untuk memperbaiki kualitas hidup manusia } \\
\text { agar dapat menekan angka kematian }\end{array}$ \\
\hline 3 & Migrasi & $\bullet$ & $\begin{array}{l}\text { Dapat memahami terbatasnya daya dukung dan daya tampung suatu daerah } \\
\text { dalam menampung jumlah penduduk yang semakin besar }\end{array}$ \\
\hline 4 & Proyeksi & Penduduk & $\begin{array}{l}\text { Dapat memahami terbatasnya daya dukung dan daya tampung suatu daerah } \\
\text { dalam menampung jumlah penduduk yang semakin besar } \\
\text { Dapat merencanakan pembangunan suatu daerah untuk mengatasi jumlah } \\
\text { penduduk yang tinggi }\end{array}$
\end{tabular}




\begin{tabular}{llll}
\hline No & Materi & $\begin{array}{l}\text { Indikator Eco-Spatial Behavior dalam Sub-Materi yang Dikembangkan } \\
\text { Peneliti }\end{array}$ \\
\hline 5 & Perencanaan & $\bullet$ & $\begin{array}{l}\text { Dapat mengambil keputusan terkait perbaikan sarana prasarana untuk } \\
\text { mengatasi permasalahan kesejahteraan penduduk yang rendah }\end{array}$ \\
& Pembangunan & $\begin{array}{l}\text { Dapat mengaitkan hubungan antara partisipasi masyarakat dalam } \\
\text { perencanaan pembangunan dengan tingkat keberhasilan menekan angka } \\
\text { kematian penduduk karena kualitas hidup yang semakin baik }\end{array}$ \\
\hline
\end{tabular}

Sumber: Hasil Analisis Peneliti

Pendekatan STEM yang terdapat pada BAD melebur menjadi satu kesatuan dari materi pokok, informasi pendukung, kegiatan siswa, dan evaluasi. Science merupakan pengetahuan mengenai konsep-konsep dan hukum-hukum keilmuan. Science dalam bahan ajar ini menekankan pada luas jangkauan materi. Unsur tautan diutamakan untuk dapat menghubungkan sumber belajar lainnya seperti data statistik pemerintah, artikel berita, dan jurnal. Selanjutnya technology, yang berarti dalam bahan ajar ini menekankan pada pencapaian keterampilan teknologi. Teknologi digunakan dengan tujuan dapat mempermudah kerja manusia. Aspek teknologi dalam bahan ajar digital terdapat pada format pengemasan bahan ajar, materi pokok, informasi pendukung, dan proyek yang ada dalam kegiatan siswa. Dalam hal ini teknologi terintegrasi dengan teknik (engineering). Teknik merupakan aplikasi dari pengetahuan sains dan keterampilan teknologi dalam menciptakan suatu. Mathematics dalam bahan ajar digital disesuaikan dengan materi perhitungan yang ada yaitu tentang pertumbuhan penduduk, fertilitas, mortalitas, dan proyeksi penduduk. Kegiatan siswa mengintegrasikan STEM dengan eco-spatial behavior. Studi observasi, wawancara, dan diskusi pada fenomena kependudukan akan memberikan dampak pada pengetahuan dan perilaku siswa.

Komponen BAD sub materi definisi dinamika penduduk, faktor dinamika penduduk (fertilitas, mortalitas, dan migrasi), proyeksi penduduk, dan perencanaan pembangunan yaitu berupa materi, gambar, infografis, video, grafik, dan tautan. Komponen yang digunakan tersebut bersumber dari pengumpulan data literatur yang dapat dipertanggungjawabkan. Selanjutnya penyusunan instrumen penelitian BAD ini berupa lembar validasi, angket tanggapan guru dan siswa. Lembar validasi ini ditujukan pada ahli materi dan media untuk mengetahui kelayakan bahan ajar yang dikembangkan.

\section{Pengembangan}

Tahap ketiga dari model pengembangan ADDIE adalah pengembangan. Tahapan ini terdiri dari beberapa tahapan yaitu deskripsi produk, validasi produk, dan revisi produk. Deskripsi produk terdiri dari beberapa unsur yaitu judul, petunjuk, kompetensi dasar, materi pokok, informasi pendukung, latihan (kegiatan siswa), dan evaluasi. Adapun tautan produk BAD yang dikembangkan sebagai berikut: https://online.flipbuilder.com/khkh/ygcp/ 


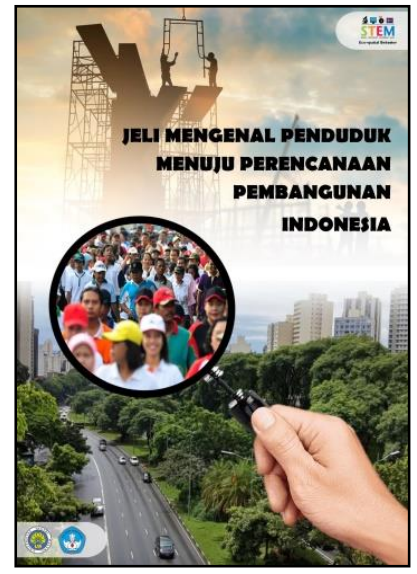

Gambar 1. Sampul Depan

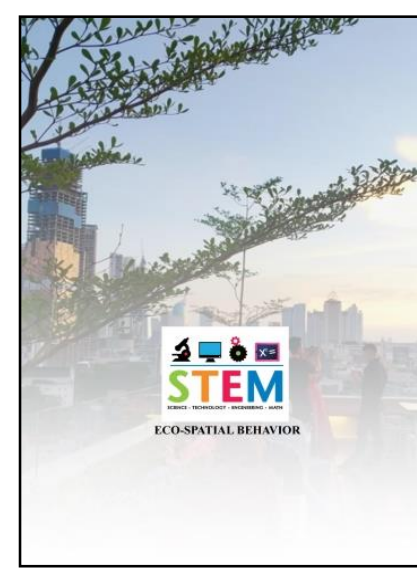

Gambar 2. Sampul Belakang

Selanjutnya hasil validasi merupakan data kuantitatif yang diperoleh melalui angket campuran yang diisi oleh dua ahli yaitu ahli materi dan media. Penentuan dua validator ahli berdasarkan kualifikasi yang dimiliki validator dan rekomendasi dari dosen pembimbing. Adapun hasil perhitungan kelayakan bahan ajar dari data kuantitatif validator sebagai berikut.

Tabel 4. Hasil Perhitungan Angket Kelayakan Validator Materi

\begin{tabular}{lll}
\hline Indikator Penilaian & Persentase Tiap Aspek & Rata-rata Persentase \\
\hline Teknik Penyajian & $100 \%$ (Sangat Layak) & \\
\hline Penilaian STEM & $75 \%$ (Layak) & (Sangat Layak) \\
\hline Penilaian eco-spatial behaviour & $75 \%$ (Layak) & \\
\hline Penyajian Materi & $100 \%$ (Sangat Layak) & \\
\hline Penyajian Pembelajaran & $100 \%$ (Sangat Layak) \\
\hline
\end{tabular}

Sumber: Hasil Penelitian

Tabel 4 merupakan hasil validasi dari lima aspek. Persentase rata-rata dari kelima aspek tersebut yaitu 90\% yang berarti sangat layak. Adapun saran-saran perbaikan yang diberikan oleh validator materi sebagai berikut: 1) revisi penggunaan kata pada tujuan pembelajaran; 2) revisi kata "natalitas" menjadi "fertilitas" dalam bahan ajar digital; 3) revisi kata kunci yang digunakan pada halaman peta konsep; 4) penambahan data kuantitatif fertilitas di dunia; dan 5) perubahan penggunaan simbol rumus GFR.

Validasi media dilakukan untuk mengetahui kelayakan media dalam bahan ajar digital yang dikembangkan. Data kelayakan diperoleh dari empat aspek penilaian yaitu desain sampul, desain isi, kelayakan penyajian, dan penyajian layout. Berikut ini hasil validasi media BAD materi kependudukan dari ahli media.

Tabel 5. Hasil Perhitungan Angket Kelayakan Validator Media

\begin{tabular}{lll}
\hline Indikator Penilaian & Persentase Tiap Aspek & $\begin{array}{l}\text { Rata-rata } \\
\text { Persentase }\end{array}$ \\
\cline { 1 - 2 } Desain Sampul Buku Digital & $88 \%$ (Sangat Layak) & $95 \%$ \\
Desain Isi Buku Digital & $100 \%$ (Sangat Layak) & \\
\cline { 1 - 2 } Kelayakan Penulisan & $100 \%$ (Sangat Layak) & \\
\hline Penyajian Layout & $94 \%$ (Sangat Layak) & \\
\hline
\end{tabular}

Sumber: Hasil Penelitian 
Tabel 5 merupakan hasil validasi dari empat aspek. Persentase rata-rata dari keempat aspek tersebut yaitu 95\% yang berarti sangat layak. Dilihat dari data kuantitatif validasi media menunjukan tingkat kelayakan sangat baik. Adapun saran-saran perbaikan yang diberikan oleh validator media sebagai berikut: 1) revisi sampul depan BAD terkait peletakan logo dan tata letak gambar dan tulisan pada sampul depan; 2) revisi template $\mathrm{BAD}$, dikarenakan untuk dapat memberikan tingkat fokus siswa yang baik dalam penggunaan BAD; dan 3) penghapusan gambar bayi pada sub materi fertilitas dalam BAD.

\section{Implementasi}

Uji coba produk BAD yang dikembangkan memiliki dua subjek uji coba yaitu guru dan siswa. Proses uji coba kepada siswa dilakukan dengan tahapan awal memberikan apersepsi dan review materi. Tahap selanjutnya memberikan review produk BAD dan diakhiri dengan pengisian angket campuran yang diberikan kepada siswa. Selanjutnya dalam proses uji coba kepada guru hanya dilakukan tahapan review produk bahan ajar selanjutnya dilakukan pengisian angket campuran. Setelah data kualitatif dan kuantitatif didapatkan, selanjutnya dilakukan proses analisis data respon guru dan siswa.

Instrumen angket tanggapan guru untuk mengetahui tingkat kelayakan BAD yang dikembangkan berdasarkan sudut pandang pendidik (guru di lokasi penelitian). Aspek teknik penyajian terdiri dari enam poin, aspek penilaian STEM terdiri empat poin, aspek penilaian eco-spatial behavior terdiri dari lima poin, aspek penyajian materi terdiri dari tiga poin, dan penyajian pembelajaran terdiri dari sembilan poin. Berikut ini hasil perhitungan angket tanggapan guru.

Tabel 6. Hasil Perhitungan Angket Tanggapan Guru

\begin{tabular}{lll}
\hline Indikator Penilaian & Persentase Tiap Aspek & Rata-rata Persentase \\
\cline { 1 - 2 } Teknik Penyajian & $83 \%$ (Layak) & $\begin{array}{l}95 \% \\
\text { (Sangat Layak) }\end{array}$ \\
\cline { 1 - 2 } Penilaian STEM & $94 \%$ (Sangat Layak) & \\
\cline { 1 - 2 } Penilaian eco-spatial behaviour & $100 \%$ (Sangat Layak) & \\
\cline { 1 - 2 } Penyajian Materi & $100 \%$ (Sangat Layak) & \\
\cline { 1 - 2 } Penyajian Pembelajaran & $97 \%$ (Sangat Layak) &
\end{tabular}

Sumber: Hasil Penelitian

Tabel 6 merupakan hasil angket tanggapan guru dari lima aspek. Persentase ratarata dari kelima aspek tersebut yaitu 95\% yang berarti sangat layak. Guru memberikan pernyataan bahwa bahan ajar digital sudah baik, memiliki fitur-fitur lengkap, dan mendukung digitalisasi.

Instrumen angket tanggapan siswa untuk mengetahui tingkat kelayakan bahan ajar digital yang dikembangkan. Pengisian angket ini dilakukan setelah siswa melihat dan menggunakan produk bahan ajar digital. Aspek desain terdiri dari lima poin, aspek sajian materi terdiri lima poin, dan aspek kemanfaatan juga terdiri dari lima poin. Berikut ini hasil perhitungan angket tanggapan siswa.

Tabel 7. Rekapitulasi Hasil Perhitungan Angket Tanggapan Siswa

\begin{tabular}{lll}
\hline Indikator Penilaian & Persentase Tiap Aspek & Rata-rata Persentase \\
\cline { 1 - 2 } Tampilan & $90 \%$ (Sangat Layak) & $87 \%$ \\
\cline { 1 - 2 } Sajian Materi & $83 \%$ (Layak) & (Sangat Layak) \\
\cline { 1 - 2 } Manfaat & $87 \%$ (Sangat Layak) & \\
\cline { 1 - 2 } & Sumber: Hasil Penelitian
\end{tabular}


Tabel 7 merupakan hasil angket tanggapan siswa dari tiga aspek. Persentase rata-rata dari ketiga aspek tersebut yaitu $87 \%$ yang berarti sangat layak. Dilihat dari data kuantitatif menunjukan tingkat kelayakan sangat baik. Adapun tanggapan-tanggapan yang diberikan siswa yaitu 1) bahan ajar sangat menarik dan tidak membosankan; 2) sangat mendukung adanya buku digital; 3) tampilan bagus dan mudah dipahami; 4) informasi yang disajikan lebih luas dibandingkan dengan bahan ajar lainnya; 5) dapat meningkatkan berpikir kreatif; 6) materi dan gambar yang disajikan menarik sehingga pembelajaran menjadi menarik; dan 7) buku digital akan memudahkan belajar kapan dan dimana saja.

\section{Evaluasi}

Tahap terakhir adalah melakukan evaluasi formatif. Evaluasi ini berhubungan dengan batasan tahapan penelitian pengembangan untuk memperbaiki produk pengembangan bahan ajar digital yang dihasilkan saja. Tahap evaluasi dilakukan di setiap tahapan ADDIE dan diakhir tahapan pengembangan produk. Tahapan terakhir evaluasi yaitu dengan mengevaluasi semua data-data yang telah didapatkan. Bahan ajar yang dikembangkan adalah bahan ajar yang mengintegrasikan pendekatan STEM dan eco-spatial behavior. Hasil pengembangan bahan ajar digital memperoleh persentase sebesar $90 \%$ dari validator materi, 95\% dari validator media, 95\% dari tanggapan guru, dan $87 \%$ dari tanggapan siswa. Hasil demikian menunjukan bahwa pengembangan bahan ajar digital berbasis STEM dengan pendekatan eco-spatial behavior sub materi dinamika kependudukan di Indonesia untuk perencanaan pembangunan sangat layak digunakan dalam pembelajaran geografi.

\section{KESIMPULAN}

Bahan ajar yang dikembangkan adalah bahan ajar yang mengintegrasikan pendekatan STEM dan eco-spatial behavior. Pendekatan ini akan menghasilkan siswa yang dapat berperilaku ekologis, memecahkan masalah, berinovasi dan dapat bersaing dalam era digital dan globalisasi. Penggunaan pendekatan ini dalam bahan ajar digital melebur menjadi satu dalam materi pokok dan kegiatan siswa. Hasil pengembangan bahan ajar digital memperoleh rata-rata persentase sebesar $92,5 \%$ dari validator materi dan validator media, rata-rata persentase $91 \%$ dari tanggapan guru dan siswa. Hasil demikian menunjukan bahwa pengembangan bahan ajar digital berbasis STEM dengan pendekatan eco-spatial behavior sub materi dinamika kependudukan di Indonesia untuk perencanaan pembangunan sangat layak digunakan dalam pembelajaran geografi.

Bahan ajar digital ini memiliki beberapa kelebihan. Kelebihan ini dapat menjadi acuan dalam mengembangkan produk dengan materi lainnya. Adapun kelebihan yang dimaksud sebagai berikut: 1) bahan ajar dikembangkan sesuai dengan perkembangan penggunaan teknologi gadget; 2) bahan ajar tidak memerlukan aplikasi khusus untuk membukanya; 3) dapat digunakan dimana dan kapan saja belajar; 4) penggunaan pendekatan STEM dan eco-spatial behavior untuk dapat melahirkan siswa yang memiliki perilaku ekologis dan dapat berinovasi untuk bersaing di era globalisasi; 5) bahan ajar dilengkapi video, tabel, grafik, gambar, foto, teks, infografis, dan tautan; 6) dapat dioperasikan di laptop, smartphone, notebook, maupun komputer.

Bahan ajar digital ini memiliki beberapa kelemahan. Kelemahan ini dapat dijadikan acuan peneliti selanjutnya untuk mengembangkan produk yang lebih baik lagi. Adapun kelemahan bahan ajar digital ini sebagai berikut: 1) bahan ajar yang dikembangkan hanya dapat diakses secara online; 2) bahan ajar dengan muatan video, 
audio, dan tautan hanya dapat diakses selama satu bulan sehingga memerlukan publikasi ulang; 3) jumlah halaman bahan ajar digital terlalu banyak 4) materi dalam bahan ajar hanya terbatas pada beberapa sub materi; 5) studi kasus yang digunakan dalam materi kependudukan banyak membahas fenomena global dalam negeri; dan 6) produk bahan ajar digital yang dikembangkan menggunakan software berbayar dan hanya dapat digunakan selama satu bulan terhitung dari tanggal publikasi bahan ajar.

\section{UCAPAN TERIMA KASIH}

Penulis mengucapkan terima kasih kepada Jurusan Geografi Fakultas Ilmu Sosial Universitas Negeri Malang yang membantu dalam pelaksanaan penelitian. Ucapan terima kasih juga kepada berbagai pihak MA Al-Ittihad Poncokusumo atas kerjasamanya sehingga terselesaikannya penelitian ini.

\section{DAFTAR PUSTAKA}

Afriana, J., Permanasari, A., \& Fitriani, A. (2016). Penerapan Project Based Learning Terintegrasi STEM untuk Meningkatkan Literasi Sains Siswa Ditinjau dari Gender. Jurnal Inovasi Pendidikan IPA, 2(2), 202-212. https://doi.org/10.21831/jipi.v2i2.8561.

Alan, R. (2013). No Shelf Required 2: Use and Management of Electronic Books. In Collection Building. https://doi.org/10.1108/CB-04-2013-0015.

Andi, P. (2011). Panduan Kreatif Membuat Bahan Ajar Inovatif: Menciptakan Metode Pembelajaran yang Menarik dan Menyenangkan. In Diva Press.

Astriyandi, A. A. (2016). Pengembangan Buku Digital Interaktif untuk Pemahaman Konsep Geografi. Jurnal Geografi Gea, 15(2), 46-58. https://doi.org/10.17509/gea.v16i1.3464.

Barry, D. M., Kanematsu, H., Lawson, M., Nakahira, K., \& Ogawa, N. (2017). Virtual STEM activity for renewable energy. Procedia Computer Science, 946-955. https://doi.org/10.1016/j.procs.2017.08.130.

Deliyanto, B. (2011). Pendekatan Eco-spatial Behavior Penghunian Rumah Susun Kota Baru Bandar Kemayoran [Institut Pertanian Bogor (IPB)]. http://repository.ipb.ac.id/handle/123456789/52688.

Hadinugrahaningsih, T., RahmawatI, Y., Ridwan, A., Budiningsih, A., Suryani, E., Nurlitiani, A., \& Fatimah, C. (2017). Keterampilan Abad 21 dan STEAM (Science, Technology, Engineering, Art, and Mathematics) Project dalam Pembelajaran Kimia. LPPM Universitas Negeri Jakarta.

Han, S. W. (2016). National Education Systems and Gender Gaps in STEM Occupational Expectations. International Journal of Educational Development, 49, 175-187. https://doi.org/10.1016/j.ijedudev.2016.03.004.

Karemaker, A., Jelley, F., Clancy, C., \& Sylva, K. (2017). The Effects on Children's Literacy Skills of Reading E-books with Different Features: Are 'bells and 
Whistles' Over-rated? International Journal of Child-Computer Interaction, 12, 30-36. https://doi.org/10.1016/j.ijcci.2017.01.004.

Kemendikbud. (2014). Permendikbud No 103 Tahun 2014. Permendikbud.

Martha, Z. D., Adi, E. P., \& Soepriyanto, Y. (2018). E-book berbasis mobile learning. Jurnal Kajian Teknologi Pendidikan, 1(2), 109-114.

Pangesti, K. I., Yulianti, D., \& Sugianti, S. (2017). Bahan Ajar Berbasis STEM (Science, Technology, Engineering, and Mathematics) untuk Meningkatkan Penguasaan Konsep Siswa SMA. UPEJ Unnes Physics Education Journal, 6(3), 53-58. https://doi.org/10.15294/upej.v6i3.19270.

Reynolds, D., Yazdani, N., \& Manzur, T. (2013). STEM High School Teaching Enhancement Through Collaborative Engineering Research on Extreme Winds. Journal of STEM Education: Innovations and Research, 14(1), 12-19.

Richter, A., \& Courage, M. L. (2017). Comparing Electronic and Paper Storybooks for Preschoolers: Attention, Engagement, and Recall. Journal of Applied Developmental Psychology, 48, 92-102. https://doi.org/10.1016/j.appdev.2017.01.002.

Ruddamayanti, R. (2019). Pemanfaatan Buku Digital dalam Meningkatkan Minat Baca. Prosiding Seminar Nasional Pendidikan Program Pascasarjana Universitas PGRI Palembaang., 364-370.

Suharsimi, A. (2006). Prosedur Penelitian Suatu Pendekatan Praktik. In Jakarta: Rineka Cipta. 